\title{
PENDIDIKAN SENI FILM DAN TELEVISI SEBAGAI PENGGERAK INDUSTRI EKONOMI KREATIF
}

\author{
Alexandri Luthfi R. \\ Dosen Jurusan Televisi, Fakultas Seni Media Rekam, ISI Yogyakarta \\ Jalan Parangtritis Km 6,5 Sewon, Bantul, DIY \\ No.HP.: 08122955141;E-mail: alexluthfi@yahoo.co.id
}

\begin{abstract}
Abstrak
Globalisasi, sebagai suatu proses integrasi internasional, terjadi karena pertukaran pandangan dunia dalam berbagai sektor. Di Indonesia gelombang globalisasi sudah bergerak lebih dari 25 tahun. Tumbuh dan berkembangnya memberikan pengaruh terhadap berbagai sisi kehidupan bangsa dengan semua atribut budayanya.Di bidang pendidikan, globalisasi memiliki dampak yang cukup besar bagi perubahan pada sistem atau model pembelajaran dan kurikulum yang diajarkan.Era industri kreatif yang digulirkan oleh pemerintah melalui Menteri Perdagangan RI,yang waktu itu masih dijabat oleh Dr. Mari Elka Pangestu, telah memberikan peluang seluas-luasnya bagi pendidikan tinggi seni agar dapat berfungsi sebagai salah satu pilar bagi pertumbuhan ekonomi kreatif di Indonesia. Indonesia sudah memiliki kantong-kantong institusi dan perusahaan yang dapat menjadi mitra bagi para lulusan pendidikan seni. Para talenta yang kreatif dan terampil lulusan pendidikan seni adalah sumber daya manusia yang diperlukan bagi sektor industri kreatif di masa mendatang. Karya film dan program acara televisi sebagai karya seni yang memiliki standart estetika, di dalamnya terdapat gagasan, pengolahan artistik, materialisasi, pengalaman teknik dan manajemen produksi, yang proses produksinya membutuhkan sekelompok atau individu sumberdaya manusia berkualitas dengan tingkat pendidikan setara diploma dan sarjana. Kemudian juga dengan televisi apabila sudah masuk ke dalam ranah industri kapitalis, tentu akan berdampak bagi masyarakatnya, seperti yang dijelaskan oleh Redatin Parwadi untuk menciptakan perilaku konsumtif bagi konsumennya inilah, televisi mempunyai peran yang sangat penting baik sebagai media ataupun sebagai alat bagi kaum kapitalis untuk mengonstruksi pikiran konsumen.Sejalan dengan konsep HAKI yang melindungi kualitas karya cipta anak bangsa dari originalitas dan eksistensinya, tentu lembaga pendidikan seni memiliki peran penting di dalam melahirkan sumberdaya manusia yang mampu menghasilkan karya seni kreatif dan inovatif. Maka dewasa ini, di Indonesia sudah saatnya menerapkan konsep pendidikan multikulturalisme berbasis budaya lokal yang dapat menjadi salah satu alternatif untuk membangun kearifan lokal menuju kebudayaan dunia.
\end{abstract}

Kata kunci: pendidikan seni, film dan televisi, industri kreatif, globalisasi, HAKI

\begin{abstract}
Art Education of Film and Television as Actuation in the Creative Economy Industry for the Lecturers of Television Department, Faculty of Recorded Media Arts ISI Yogyakarta. Globalization, as a process of international integration, occurs because there is an exchange of the world's view in some sectors. In Indonesia, the wave of globalization has been ongoing for more than 25 years. Its growth and development have given influence to all aspects of nation's life with its cultural attributes. In education, globalization has a quite big impact for the shift of system or learning model and the taught curriculum. The era of creative industry launched by the government through the Indonesian Minister of Trade which was once held by Dr. Mari Elka Pangestu, has now given a vast opportunity for higher education in art to be one of the pillars for the growth of creative economy in Indonesia. Indonesia has certain institutions and companies that could be partners for the graduates of art school. Creative talents and skillful graduates from art school are the necessary human resources for creative industry sector in the future. Films and television programs as works of art which has standardized aesthetics, therein we could find ideas, artistic process, materialization, technique and production management experience, whose production processes need a group of people or
\end{abstract}


qualified human resources holding diplomas of bachelor degree and bachelor of honors or those in equivalence. When television is admitted into capitalist's industry, it will affect the society, as stated by Redatin Parwadi, to create a consumptive behavior for the consumers, television has an important part both as media and as means for the capitalists to construct the mind of the consumers. In accordance with the concept of HAKI (intellectual rights) to protect the quality of copyrights owned by the nations' generation with their originality and existence, higher education of arts has a very significant role in creating human resources who are able to create creative and innovative works of art. Nowadays, Indonesia has already applied multiculturalism education concept on the basis of local wisdom that could be one of alternatives to build local wisdom into world's culture.

Keywords: art education, film and television, creative industry, globalization, HAKI

\section{PENDAHULUAN}

Globalisasi, sebagai suatu proses integrasi internasional, terjadi karena pertukaran pandangan dunia dalam berbagai sektor. Pergerakan globalisasi telah berhasil membangun suatu sistem informasi yang mampu memengaruhi perkembangan budaya, ilmu pengetahuan, dan teknologi. Kemudian para pakar bidang kebudayaan menyebutnya sebagai sebuah proses terbentuknya sistem organisasi dan komunikasi antarmasyarakat di seluruh dunia untuk mengikuti sistem dan kaidah tertentu yang sama, dengan memandang globalisasi pada perilaku dan kualitas individu yang mampu menjangkau satu dengan yang lain atau saling berhubungan dalam semua aspek kehidupan mereka, baik dalam budaya, ekonomi, politik, teknologi, maupun lingkungan hidup.

Di Indonesia gelombang globalisasi sudah bergerak lebih dari 25 tahun. Tumbuh dan berkembangnya memberikan pengaruh terhadap berbagai sisi kehidupan bangsa dengan semua atribut budayanya. Akibat nyata dari dampaknya adalah membawa perubahan yang sangat cepat dengan berbagai persoalannya dan ini menjadi tantangan sekaligus dapat menjadi suatu proses menuju pada kemajuan negara yang sesungguhnya sangat kuat dengan memiliki banyak beragam suku dan budaya. Oleh karena itu, ketika globalisasi dengan niscaya masuk, telah menghantarkan negara ini terlibat ke dalam satu sistem yang mendunia dan konsekuensinya harus diciptakan etos kerja yang tinggi dengan pola berpikir yang baik berdisiplin dalam memajukan ipteks, yaitu ilmu pengetahuan, teknologi, dan seni.

Di bidang pendidikan, globalisasi memiliki dampak yang cukup besar bagi perubahan pada sistem atau model pembelajaran dan kurikulum yang diajarkan. Banyak para pakar pendidikan menyebutnya bahwa pengaruh globalisasi membawa berkah sekaligus juga masalah, apalagi sistem pendidiksn selalu berubah-ubah mengikuti kebijakan pimpinan pada saat itu. Kemudian yang terjadi adalah hilangnya identitas pendidikan dengan menuduh arus globalisasi telah membawa pada situasi ambivalensi, yaitu berada pada kebingungan karena ingin mengejar ketertinggalan untuk menyamai kualitas pendidikan berskala internasional. Permasalahan ini tentunya akan membuat Indonesia pada situasi krisis moral atau hilangnya jati diri sebab pendidikan menurut pandangan saya merupakan identitas bangsa.

Kebijakan selanjutnya ketika pemerintah berusaha merespons problematika nasional ini sebagai masalah yang serius dan harus dilakukan tindakan nyata, kemudian dilakukan langkah tepat, yaitu menyikapi pengaruh globalisasi dengan melakukan perubahan besar terhadap konsep pendidikan seni di negeri ini. Langkah yang ditempuh oleh pemerintah menjadi nyata ketika 
digulirkannya konsep kurikulum nasional yang berbasis pada potensi dan nilai-nilai budaya. Invasi budaya global masuk dengan sangat kuat sehingga memberi pengaruh juga terhadap karakteristik sistem pendidikan di Indonesia, seperti konsep otonomisasi, model pembelajarannya, dan dengan perubahan kebijakan Undang-Undang BHP serta konsep kurikulum yang berlandaskan pada nilainilai budaya lokal. Oleh sebab itu, di dalam prosesnya pendidikan adalah menuntun segala kekuatan kodrat yang ada pada anak-anak agar tumbuh sebagai seorang pribadi dan menjadi bagian dari sebuah bangsa. Pemikiran di atas sejalan dengan Undang-Undang Sisdiknas bahwa pendidikan nasional berfungsi untuk mengembangkan kemampuan dan membentuk watak serta peradaban bangsa yang bermartabat. Tujuannya adalah untuk mengembangkan potensi anak didik agar menjadi manusia yang beriman, bertakwa, berakhlak mulia, sehat, berilmu, cakap, kreatif, mandiri, dan menjadi warga negara demokratis serta bertanggung jawab (UU Sisdiknas, 2003, Pasal 3).

Multikulturalisme atau pluralisme yang dimiliki oleh bangsa ini sesungguhnya dapat dimasukan ke dalam konsep pendidikan, tujuannya untuk mensosialisasikan keberagaman budaya dengan nilai-nilai lokalnya. Mengakulturasi budaya global menjadi bagian dari proses pendidikan merupakan wujud dari keterbukaan pendidikan seni yang mendunia. Mozaik budaya yang kita miliki adalah identitas etnik, di dalamnya terdapat kandungan kearifan lokal yang dapat disandingkan berjalan berdampingan bersama budaya global. Nilai-nilai budaya lokal yang kita miliki menciptakan peradaban yang tinggi sebagai suatu bangsa yang pluralis. Konsepsinya adalah halus dan indah yang menghasilkan wujud kesenian,ilmu pengetahuan dan teknologi.

Maka sehubungan dengan perkembangan dan peningkatan kualitas pendidikan seni perlu diciptakan sikap menerima adanya keberagaman, yaitu asimilasi antarbudaya etnik dengan budaya global sebagai jalan menuju sistem pendidikan seni yang berkarakter dunia. Oleh karena itu, kurikulum pendidikan sebaiknya dilengkapi dengan pendidikan multikultural, yang mempertemukan kebudayaan lokal dengan kebudayaan-kebudayaan lain. Tujuannya adalah mencapai orisinalitas dan identitas.

\section{PEMBAHASAN}

\section{Persoalan yang Dihadapi oleh Pendidikan Seni}

Pendidikan seni di Indonesia kini usianya sudah menginjak 67 tahun. Di kota-kota besar di berbagai daerah dan provinsi sudah memiliki sekolah menengah kejuruan seni, akademi seni, sekolah tinggi seni, dan institut seni. Bidang ilmu kajian seni dan penciptaan yang selama ini dipelajari dan diproduksi merupakan pengejawantahan dari jati diri budaya bangsa. Oleh sebab itu, hal ini perlu mendapatkan perhatian dalam sistem pendidikan untuk memperkuat identitas dan kesadaran nasional.

Pemerintah dengan pendidikan tinggi seni yang dimiliki dan berada di kota besar di Indonesia, dewasa ini sedang terus-menerus dalam proses membangun, menghidupkan, mengembangkan, dan melestarikan seni budaya Nusantara sebagai aset menuju industri ekonomi kreatif yang harus ditangani secara saksama dan komprehensif. Maka tantangan dan peluang yang ditimbulkan dari gerakan globalisasi dengan industri kreatif adalah meningkatnya kebutuhan sumber daya manusia yang kreatif dan memiliki jiwa kewirausahaan. Persoalan ini tentunya memerlukan perhatian dan penanganan secara serius dan terprogram serta berkelanjutan karena ada banyak persolan yang harus dihadapi. Pendidikan seni menempati posisi yang sangat strategis sebagai garda depan mengawal berbagai masalah yang harus dihadapi oleh negeri ini dalam upayanya meningkatkan kesenian Indonesia menjadi kekuatan ekonomi kreatif yang 
meliputi sumber daya manusia, produksi, dan manajemennya. Adapun masalah-masalah yang nyata dan harus dipecahkan adalah: (1) melemahnya pengertian pendidikan seni sebagai inisiasi budaya akibat pengaruh globalisasi; (2) secara perlahanlahan di berbagai wilayah di Indonesia, kebudayaan lokal dan tradisional melemah, didominasi oleh budaya global; (3) kebudayaan dalam hubungannya dengan ekonomi kreatif mempunyai tiga wujud, ideide (pemikiran), kebiasaan (perilaku), dan material (artefak); (4) ekonomi kreatif yang digerakkan oleh kreator dan inovator yang menghasilkan produk atau jasa dengan kandungan seni belum sepenuhnya diberdayakan sebagai industri kreatif; dan (5) pelaku kreatif atau sarjana seni terkendala oleh melemahnya jiwa kewirausahaan.

Berdasarkan berbagai tantangan tersebut pemerintah Indonesia dan seluruh elemen masyarakat harus dapat menciptakan gerakan diplomasi seni dan budaya guna mempertegas kehadiran potensi kearifan lokal yang ada di dalam mozaik budaya Indonesia. Kemudian peran dari pendidikan seni adalah menyiapkan sumber daya manusia yang kreatif dalam berkarya dan memiliki jiwa kewirausahaan.

\section{Peluang Pendidikan Tinggi Seni}

Era industri kreatif yang digulirkan oleh pemerintah melalui Menteri Perdagangan RI waktu itu masih dijabat oleh Dr. Mari Elka Pangestu, telah memberikan peluang seluas-luasnya bagi pendidikan tinggi seni agar dapat berfungsi sebagai salah satu pilar bagi pertumbuhan ekonomi kreatif di Indonesia. Ketegasan dan tekad pemerintah menangani industri kreatif yang berbasis pada pendidikan seni tercermin pada penghargaan kualitas kreativitas individu yang dihasilkan dari sebuah proses akademik. Bidang-bidang kelompok industri kreatif yang digulirkan oleh departemen perdagangan, seluruhnya mengindikasikan bahwa pendidikan seni diharapkan dapat mendukung melahirkan individu dan kelompok masyarakat kreatif serta mampu memberikan kontribusi yang cukup signifikan baik terhadap pertumbuhan ekonomi nasional maupun global.

Perguruan tinggi seni sesungguhnya memiliki potensi sebagai pendukung pertumbuhan berbagai aspek industri kreatif seperti penciptaan karya seni yang kreatif berbasis pada nilai tradisi lokal dan teknologi multimedia (televisi dan film). Karya-karya seni dengan nilai tradisi lokal yang merupakan hasil dari kolaborasi dengan teknologi multimedia memiliki peluang menjadi produk inovasi yang dapat menjadi kebangkitan dan era baru masyarakat modern di Indonesia.

Indonesia sudah memiliki kantong-kantong institusi dan perusahaan yang dapat menjadi mitra bagi para lulusan pendidikan seni. Para talenta yang kreatif dan terampil lulusan pendidikan seni adalah sumber daya manusia yang diperlukan bagi sektor industri kreatif di masa mendatang. Sebut saja industri multimedia di Indonesia sebagai entitas bisnis sangat diwarnai oleh tampilan keberagaman materi yang memerlukan penanganan sumber daya manusia yang terampil dan kreatif. Demikian juga dengan industri film dan televisi yang tumbuh melalui production house, studio-studio, dan stasiun televisi. Dari semua itu sangat memerlukan sumber daya manusia yang profesional, kreatif, dan inovatif.

Oleh sebab itu, pemecahan persoalan ini tentu akan melibatkan perguruan tinggi seni dengan model kurikulumnya, bersama kebijakan pemerintah dan keterlibatannya secara langsung terhadap peran stake holder agar dapat membantu mengontrol perkembangan dunia industri multimedia di negeri ini. Seperti yang dijelaskan oleh Widodo Muktiyo, networking perguruan tinggi dengan dunia usaha. Kemudian disampaikan kepada lingkaran berikutnya stake holder yang lebih luas lagi, yaitu community dengan berbagai komponennya seperti organisasi 
masyarakat. Setelah itu dengan dunia yang lebih luas lagi, sampai pada costumer luar daerah atau luar negeri (Muktiyo, 2006). Uraian ini seakan menegaskan kembali pentingnya koordinasi dan kerja sama dari berbagai pihak yang terkait baik secara langsung maupun tidak langsung terhadap tumbuh dan berkembangnya perguruan tinggi seni sebagai salah satu potensi guna menciptakan sumber daya manusia yang kreatif dan berjiwa kewirausahaan.

\section{Potensi Film dan Televisi dengan Tantangannya}

Karya film dan program acara televisi sebagai karya seni yang memiliki standar estetika di dalamnya terdapat gagasan, pengolahan artistik, matrialisasi, pengalaman teknik, dan manajemen produksi, yang proses produksinya membutuhkan sekelompok atau individu sumber daya manusia berkualitas dengan tingkat pendidikan setara diploma dan sarjana.

Oleh sebab itu, produk film dan televisi yang berkualitas idealnya memiliki fungsi memberikan penerangan dan edukasi kepada masyarakat. Maka ukuran yang dapat dipakai untuk mencapai standardisasi estetika adalah yang berkaitan dengan konten dan pesannya, yaitu berkualitas dari segi informasi dan segi idukasi agar masyarakat dari tingkat bawah sampai tingkat akademik dapat memperoleh manfaat. Arini Hidayati menegaskan di dalam bukunya bahwa keberadaan media massa televisi, pada dasawarsa terakhir ini, memang semakin menarik perhatian masyarakat (termasuk Indonesia). Munculnya siaran-siaran televisi "komersial" swasta semakin menyemarakkan dunia pertelevisian (Hidayati, 1998). Tentunya pandangan Arini ini akan membawa dampak terhadap masyarakat dalam berbagai lapisan strata sosial dengan tingkat pendidikannya.

Demikian halnya dengan karya film, Gayus Siagian membicarakan film sebagai karya seni dengan sendirinya kita memakai ukuran-ukuran estetika yang umum diterima di dunia seni. Di dalam hal ini kita melihat film dalam keseluruhannya sebagai suatu finhished product, sebagaimana kita menilai sebuah lukisan, arca, roman atau komposisi musik/lagu (Siagian, 2006).

Potensi film dan program acara televisi sesungguhnya sudah lama memiliki nilai jual dan dapat digolongkan sebagai produk industri kreatif. Dengan demikian, di dalam perkembangannya selalu berbenturan dengan banyak kepentingan yang dapat memengaruhi segi kualitas. Seperti yang dijelaskan oleh Gayus Siagian bahwa bilamana kita melihat film hanya atau terutama sebagai barang dagangan atau perusahaan film itu sebagai industri hiburan yang memprodusir hiburan untuk massa, maka dengan sendirinya kita berpikir dalam istilah dagang, cost accounting, yang tidak berpotensi seni (Siagian, 2006). Kemudian juga dengan televisi apabila sudah masuk ke dalam ranah industri kapitalis, tentu akan berdampak bagi masyarakatnya, seperti yang dijelaskan oleh Redatin Parwadi untuk menciptakan perilaku konsumtif bagi konsumennya inilah, televisi mempunyai peran yang sangat penting baik sebagai media maupun sebagai alat bagi kaum kapitalis untuk mengonstruksi pikiran konsumen. Televisi juga merupakan bagian yang tidak terpisahkan dari kaum kapitalis untuk membujuk, membius, dan menekan konsumennya agar mengikuti apa yang diinginkan (Parwadi, 2004). Selanjutnya Muzayin Nazaruddin menegaskan bahwa tingkah laku industri penyiaran akan ditentukan logika akumulasi kapital. Dalam ranah siaran televisi, kuatnya pengaruh dan kepentingan modal akan menghasilkan beberapa hal: tayangan yang seragam serta kecenderungan pada program-program hiburan (Nazaruddin \& Hermanto, 2009). Mencermati ketiga penjelasan tersebut, produksi karya film dan televisi ketika masuk dalam ranah industri dengan tantangan utamanya adalah bagaimana upaya 
mempertahankan kualitas produksi yang mengacu pada standardisasi estetika atau larut terbawa oleh kuatnya jaringan kapitalis bisnis film dan televisi.

Begitu pentingnya fungsi televisi sebagai media komunikasi yang berpotensi mampu mencerdaskan anak bangsa, Garin Nugroho menguraikan pandangannya, sesungguhnya televisi yang senantiasa diletakkan di tempat paling strategis di ruang-ruang keluarga Indonesia, pada hakikatnya adalah medium politik informasi dan komunikasi di ruang keluarga, di sisi lain, televisi lewat programprogramnya, dari berita, sinetron hingga kuis maupun talk show, sesungguhnya bukan sekadar hiburan di ruang hampa (Nugroho, 2002).

Karya seni sebagai produk kreatif dan berkembang menjadi industri kreatif, tentu diharapkan tetap berada di jalur kreativitas yang mampu membangkitkan semangat dan sendi-sendi kehidupan sosial yang telah rapuh oleh kuatnya pengaruh industri kapitalis. Kehadiran pekerja seni dengan karya-karya kreatifnya bermakna positif bagi perkembangan masyarakatnya khususnya di dalam dimensi-dimensi kehidupannya. Ekspresi seni dan fungsinya di dalam konteks estetika, yaitu nilai-nilai keindahan pada karya seni, Nyoman Kutha Ratna menjelaskan fungsi utama karya seni melalui aspek keindahannya adalah memberikan kesenangan dan ketenangan, kenikmatan dan kesejukan, keharmonisan, dan keserasian (Ratna, 2015). Artinya penjelasan yang diuraikan ini, tetap fokus pada fungsi karya seni untuk membangun kualitas kehidupan manusia dengan berbagai aspek kehidupan sosial, moral, dan pendidikannya.

Ekspresi seni sangat berbeda dengan ungkapan emosi atau perasaan. Ungkapan emosi lebih bersifat subjektif dan personal, sedangkan ekspresi seni menawarkan nilai-nilai keindahan yang sengaja diciptakan dalam karya seni untuk memberikan rangsangan kepada manusia agar menjadi larut dan terpengaruh. Oleh Langer ekspresi seni menuntut adanya suatu perwujudan material, supaya karya seni tidak hanya berhenti sebagai imajinasi. Kemudian Langer menyimpulkan karya seni mempunyai nilai edukatif, karena seni menyimpan konsepsi keindahan dan menanamkan konsepsi ini ke dalam perasaan masyarakat. Namun pola pendidikan ini tidak langsung atau terang-terangan,. Dengan kehalusan dan ciri simbolnya yang khas itu, seni mengajak publik untuk mengalami nilai-nilai keindahan yang sudah dihayati si seniman (Sastrapratedja, 1983).

Kembali pada potensi film dan televisi dengan tantangannya, karya film dan program acara televisi sebagai ekspresi seni di dalam proses kreatifnya serta produksinya tentu tidak sama seperti seni yang bersifat individualistis. Hal ini karena karakteristik dari karya film dan televisi di dalam proses produksi dan kontribusinya melibatkan banyak pihak. Seperti produsen film, rumah produksi dan kontributor, semuanya memiliki peran dan cenderung banyak memberikan warna serta bentuk pada karya film dan televisi. Raymond Williams menguraikan pandangannya bahwa televisi saat ini telah menjadi suatu layanan utama bagi seluruh generasi. Televisi berdampak secara persis sebagaimana maksud-maksud eksplisit yang dinyatakan secara terbuka oleh berbagai tokoh dari institusi-institusi televisi. Namun, televisi juga memiliki efek-efek yang tidak terduga sebelumnya, di antaranya ialah memunculkan hasrat untuk menggunakan teknologi demi dirinya sendiri. Anakanak muda radikal antikemapanan, dan terlebih lagi anak-anak dari kultur antikemapanan sangat akrab dengan media dan sangat suka bereksperimen dan beraktivitas media (Williams, 2009). Penjelasan ini menegaskan betapa pentingnya sikap kritis dan inspiratif terhadap media televisi, yang dapat mendorong perilaku yang kreatif dan inovatif terhadap media televisi, baik dari aspek teknologinya maupun estetikanya. 
Persoalan ini tentunya akan menjadi tantangan bagi para kreator-kreator pekerja film dan televisi, untuk lebih fokus memosisikan aset seni budaya Indonesia sebagai inspirasi, dan juga dasar filosofi penciptaan yang mampu menghasilkan bentuk atau wujud karya seni dengan standar estetika budaya Indonesia. Dengan demikian, peranan serta fungsi film dan televisi yang berpotensi sebagai salah satu penggerak industri kreatif dapat menjadi tolok ukur bagi produk-produk seni lainnya.

\section{SIMPULAN}

Ketika globalisasi sudah menjadi hal yang niscaya harus dihadapi, Indonesia sebagai negara yang multikulktural dan pluralisme harus memiliki konsep pendidikan seni yang menempatkan estetika sebagai aspek penting untuk melahirkan karya cipta yang bernilai tinggi. Nilai-nilai estetika hendaknya teraktualisasikan di dalam kurikulum pendidikan seni dan berisikan dua hal pokok yang harus diwujudkan ke dalam karya seni, yaitu unsur orisinalitas dan identitas. Keduanya amat esensial dalam proses kreasi untuk mencari bentuk menuju vision of the world.

Indonesia yang memiliki banyak suku dengan bentuk keseniannya dapat menjadi sumber inspirasi yang tidak akan pernah kering, maka dengan niscaya kekayaan budaya dan seni yang dimiliki apabila dapat ditempatkan sebagai dasar bentuk serta filosofi penciptaan karya seni, tentu akan menghasilkan karya seni yang indah dan idukatif. Kekayaan aspek-aspek kebudayaan yang dimiliki tentu membawa manfaat untuk memberikan pencerahan kehidupan manusia yang notabene juga merupakan hasil dari kecerdasan estetika bangsa Indonesia.

Pendidikan seni di Indonesia, agar dapat menjadi penggerak bagi berkembangnya industri kreatif menuju tercapainya program ekonomi kreatif, perlu tindakan reaktualisasi pola pikir tentang pentingnya estetika menjadi landasan konsep pendidikan yang dapat menciptakan dan membentuk kepribadian dengan nilai-nilai luhur budayanya. Meskipun karya seni film dan televisi hanyalah sebagian kecil dari kekuatan pilarpilar berkembangnya industri ekonomi kreatif di Indonesia, tentu di dalam implementasiannya ketika bersentuhan langsung dengan khalayak masyarakat, akan berdampak secara sosial, moral, dan pendidikan. Di dalam karya seni terdapat dampak yang bisa memengaruhi mental manusia. Hal ini disebabkan oleh kualitas keindahan yang diproduksi telah menjadi konsumsi psikologis.

Kemudian untuk meredam dampak negatif yang ditimbulkan oleh karya seni film dan televisi dari terbentuknya perilaku konsumtif, karya seni film dan televisi sebagai media komunikasi yang sarat akan terbentuknya nilai-nilai baru yang berasaskan komersialisasi dan kapitalis, perguruan tinggi seni sebagai lembaga institusi pendidikan bertanggung jawab terhadap persoalan ini. Adapun langkah-langkah penting yang harus dilakukan untuk membangun sinergi kekuatan bersama antara lembaga pendidikan, pemerintah, media, dan pelaku industri kreatif, di dalam memecahkan persoalan ini, adalah: (1) menciptakan wawasan kebangsaan berbasis budaya kepada seluruh lapisan pendidikan; (2) membuka jejaring internasional melalui program muhibah seni dan pariwisata, sebagai media promosi bagi produk industri kreatif; (3) karakteristik film dan televisi sebagai media kreatif yang masuk ke dalam subsektor industri kreatif mampu memberikan pengaruh kuat pada pencitraan budaya bangsa; (4) ekonomi kreatif, dalam konteks industri kreatif, faktanya pendidikan seni di Indonesia memiliki potensi lebih dari 10 subsektor industri kreatif masih perlu dipertegas dan dikembangkan potensinya; dan (5) membangun kurikulum berbasis budaya Indonesia dan kewirausahaan. 
Sebagai bangsa yang besar, Indonesia telah bergerak maju menggalang kekuatan keragaman budayanya ke dalam ranah pendidikan formal, salah satunya dengan mendirikan pendidikan seni. Dorongan untuk mendirikan pendidikan seni ini, menyadari bahwa pendidikan seni dapat menjadi salah satu basis dari industri kreatif bertaraf internasional. Indonesia yang terdiri dari banyak pulau dengan potensi seni budayanya, memiliki banyak potensi sumber daya manusia yang kreatif dan inovatif. Dengan demikian, Indonesia harus optimis dan mampu menjawab tantangan gelombang globalisasi khususnya terhadap bidang pendidikan dan ekonomi. Kemudian apabila mencermati hasil kreativitas anak bangsa hasil dari proses pendidikan, sudah banyak diciptakan karya seni film dan televisi yang sepatutnya diakui secara institusional sebagai karya seni yang dilindungi hak kekayaan intelektualnya. Tim Lindsey menjelaskan bahwa HAKI pada umumnya berhubungan dengan perlindungan penerapan ide dan informasi yang memiliki nilai komrsial. HAKI adalah kekayaan pribadi yang dapat dimiliki dan diperlakukan sama dengan bentuk-bentuk kekayaan lainnya (Lindsey, 2006).

Sejalan dengan konsep HAKI yang melindungi kualitas karya cipta anak bangsa dari originalitas dan eksistensinya, tentu lembaga pendidikan seni memiliki peran penting di dalam melahirkan sumberdaya manusia yang mampu menghasilkan karya seni kreatif dan inovatif. Maka dewasa ini, di Indonesia sudah saatnya menerapkan konsep pendidikan multikulturalisme berbasis budaya lokal yang dapat menjadi salah satu alternatif untuk membangun kearifan lokal menuju kebudayaan dunia.

\section{KEPUSTAKAAN}

Hidayati, A. (1998). Televisi dan Perkembangan Sosial Anak. Yogyakarta: Pustaka Pelajar.

Lindsey, T. (2006). Hak Kekayaan Intelektual Suatu Pengantar. Bandung: P.T. Alumni.

Muktiyo, W. (2006). Membangun Usaha Dengan Kekuatan Image. Yogyakarta: Pinus.

Nazaruddin, M., \& Hermanto, B. (2009). Televisi Komunitas Pemberdayaan Dan Media Literasi. Jakarta.

Nugroho, G. (2002). TV Publik Menggagas Media Demokratis di Indonesia. Jakarta: SET Jakarta. Parwadi, R. (2004). Televisi Daerah Di Antara Himpitan Kapitalisme Televisi. Pontianak: Badan Penerbit Universitas Tanjung Pura Pontianak.

Ratna, N. K. (2015). Estetika Sastra dan Budaya. Yogyakarta: Pustaka Pelajar.

Sastrapratedja, M. (1983). Manusia Multi Dimensional. Jakarta: PT. Gramedia.

Siagian, G. (2006). Menilai Film. Jakarta: Cipta Dewan Kesenian Jakarta.

Williams, R. (2009). Televisi. Yogyakarta: Resist Book. 